University of Nebraska - Lincoln

DigitalCommons@University of Nebraska - Lincoln

Faculty Publications: Department of

Entomology

Entomology, Department of

2008

Using Banded Sunflower Moth (Lepidoptera: Tortricidae) Egg

Density to Estimate Damage and Economic Distance in Oilseed

Sunflower

Kirk D. Mundal

North Dakota State University

Gary J. Brewer

University of Nebraska-Lincoln, gbrewer2@unl.edu

Follow this and additional works at: https://digitalcommons.unl.edu/entomologyfacpub

Part of the Entomology Commons

Mundal, Kirk D. and Brewer, Gary J., "Using Banded Sunflower Moth (Lepidoptera: Tortricidae) Egg Density to Estimate Damage and Economic Distance in Oilseed Sunflower" (2008). Faculty Publications:

Department of Entomology. 221.

https://digitalcommons.unl.edu/entomologyfacpub/221

This Article is brought to you for free and open access by the Entomology, Department of at DigitalCommons@University of Nebraska - Lincoln. It has been accepted for inclusion in Faculty Publications: Department of Entomology by an authorized administrator of DigitalCommons@University of Nebraska - Lincoln. 


\title{
Using Banded Sunflower Moth (Lepidoptera: Tortricidae) Egg Density to Estimate Damage and Economic Distance in Oilseed Sunflower
}

\author{
KIRK D. MUNDAL ${ }^{1}$ AND GARY J. BREWER ${ }^{2}$
}

\begin{abstract}
J. Econ. Entomol. 101(3): 969-975 (2008)
ABSTRACT The banded sunflower moth, Cochylis hospes Walsingham (Lepidoptera: Tortricidae), is an important economic pest of sunflower in the Upper Great Plains of North America. Economic losses due to reductions in seed number, weight, and quality can be significant. Previously, the potential for economic losses were estimated by sampling for adult moths. However, sampling for moths can be difficult and inaccurate. An alternative is to sample for banded sunflower moth eggs, which can be accurately counted in the field by using a binocular 3.5 headband magnifier. The egg counts are used to calculate the economic injury level (EIL) (EIL $=\mathrm{C} / \mathrm{VWPK}$ ), where $\mathrm{C}$ is the cost of treatment per unit area, $\mathrm{V}$ is the crop market value per unit of weight, $\mathrm{W}$ is the slope of the regression between banded sunflower moth egg densities and weight loss per plant, $\mathrm{P}$ is a term for plant population per unit area, and $\mathrm{K}$ is the control treatment efficacy. Estimates of populations of banded sunflower moth eggs are taken from the center of 400-m spans along all field sides. From these samples and the calculated EIL, a map of the extent of the economically damaging banded sunflower moth population throughout the field is made using economic distance; $\mathbf{E D}=\mathrm{e}^{((\mathbf{E I L} / \mathbf{E})-1.458) /-0.262)}$. Economic distance estimates the distance an economic population extends into the field interior along a transect from the sampling site. By using egg samples to calculate the EIL and mapping the distribution of economic populations throughout a field, producers can then make more effective pest management decisions.
\end{abstract}

KEY WORDS sampling, EIL, economic distance, Helianthus annuus, Cochylis hospes

Larvae of the banded sunflower moth, Cochylis hospes Walsingham (Lepidoptera: Tortricidae), feed on developing sunflower seeds, and they are a serious pest of cultivated sunflower (Helianthus annuus L.) in the northern Great Plains (Charlet and Busacca 1986). Moths emerge from the soil in early July and emergence continues into August (Charlet and Gross 1990).

The economic injury level (EIL) developed by Charlet et al. (2002) requires sampling 100 plants for moths. However, sampling a field for moths may underestimate the population size because in some cases, a portion of the population may be congregating (staging) outside the field during the daylight period. Additionally, banded sunflower moths are small, take flight with little disturbance, and those adults that remain in the sunflower field are difficult to locate in the dense vegetative canopy of the sunflowers. Consequently, sunflower growers may not have the necessary time or skills to accurately sample moths. A time-efficient, convenient, and more accurate option to sampling for moths is needed.

\footnotetext{
${ }^{1}$ Department of Entomology, North Dakota State University, Hultz Hall, 1300 Albrecht Blvd., Fargo, ND 58105.

${ }^{2}$ Corresponding author: Department of Entomology, University of Nebraska-Lincoln, 202 Entomology Hall, P.O. Box 830816, Lincoln, NE 68583 (e-mail: gbrewer2@unl.edu).
}

An alternative is to sample eggs as a predictor of larval population density. Most banded sunflower moth eggs are deposited on the outer surfaces of floral bracts and the back of the bud (Beregovoy and Riemann 1987), and although the eggs are small $(0.4 \mathrm{~mm})$, they are easy to locate. Eggs are oviposited singly or in small, sometimes overlapping clusters (Bergmann 1989), and plant stages R3 to R4 (Schneiter and Miller 1981) are preferred for oviposition (Beregovoy and Riemann 1987). Because a portion of the moths stage outside the field (Peng and Brewer 1996), more eggs are oviposited on the margins of the field than in the interior (edge effect).

Peng and Brewer (1996) developed a method to estimate the total banded sunflower moth egg population on a floral bud by counting eggs on six randomly selected bracts from the outer whorl of the bud. However, they did not quantify the relationship between egg densities and subsequent yield losses. Knowing the relationship between egg densities and yield loss is a critical element in the development of a new EIL.

Total seed weight per area is the principal yield parameter for oilseed sunflower growers. Another yield parameter contributing to producer profits is the oil percentage of the sunflower seed. To date, oil percentage has not been considered in a banded sunflower moth EIL, although it is included in the EIL for the red sunflower seed weevil (Peng and Brewer 1995). 
The goal of this study was to develop sampling and decision-making techniques that are profitable and easier to use than existing procedures. Objectives were to develop a method to accurately and efficiently count banded sunflower moth eggs on plants in the field, to relate egg distributions at field margins to whole field distributions, to relate infestation levels at different plant stages to yield parameters, and to develop economic decision-making techniques for the banded sunflower moth.

\section{Materials and Methods}

Egg Sampling. We tested several egg sampling procedures in an attempt to adapt the techniques of Peng and Brewer (1996) for field use. We compared four sampling methods for accuracy and ease of use. Sunflower buds at plant stage R3 that had visible infestations of banded sunflower moth eggs were harvested in late July 2003 from research plots at Prosper, ND, and they were taken to the laboratory. Six randomly selected bracts from the outer whorl of each bud were removed for evaluation. The number of banded sunflower moth eggs on each bract was counted by 1 ) using unaided vision, 2) using a handheld, $2 \times$ magnifying glass, 3) evaluating a 5.1 mega pixel digital photograph of each bract taken with a Nikon E5000 digital camera, and 4) using a binocular headband 3.5 magnifier (OptiVISOR Da-10, Donegan Optical Company, Inc., Lenexa, KS ). Absolute egg densities on each bract were obtained by counting eggs through a dissecting microscope.

Ten inexperienced individuals were asked to count the eggs on each bract by using each sampling method. Analysis of variance (ANOVA) was used to compare the numbers of eggs counted by each method. Means were separated using least significant difference (LSD) (PROC ANOVA, SAS Institute 1999).

In-Field Sampling. To determine an appropriate linear spacing between sample sites in commercial sunflower fields, five bud samples were taken at $\approx 100$-m intervals around the margins of fields sampled. In 2003, four fields near Kindred and one field near Valley City, ND, were sampled. In 2004, three fields were sampled; one field each near Valley City, Wimbleton, and Courtney, ND. The fields sampled ranged from 33 to 130 ha. Each sample site was located $\approx 6 \mathrm{~m}$ (seven rows) from the field edge. At each sample site, the eggs on six bracts per R3 stage bud were counted in the field using the head-mounted, $3.5 \mathrm{mag}$ nification method described above. Five plants per site were sampled.

Because eggs were sampled along all sides of each field, we were able to compare egg numbers for whole fields (all sites from all sides of each field), field-sides (only those sites along individual field sides), and partial field-sides (within 400-m spans of a field side) to determine whether egg populations were consistent within each scale of analysis (PROC ANOVA, SAS Institute 1999). A field side was defined as any portion of a field margin that extended for at least $100 \mathrm{~m}$ in a more or less straight line. Because the size and the number of sides per field were different, the number of sample sites per field was not uniform. For the fields sampled, field sides ranged from 200 to 1,300 $\mathrm{m}$ in length. The egg counts from the five buds sampled per site were averaged and compared against other sample sites by using ANOVA. Separate analyses were done for whole fields, field-sides, and partial field-sides.

In a separate analysis, the likelihood of an egg count at any specific site being statistically the same as those at distances of 100, 200, and $300 \mathrm{~m}$ to either side of the original sample site was tested using the Press statistic (PROC Reg and PROC Press, SAS Institute 1999). The Press statistic uses residuals output from regression analysis to test whether the value of a specific sample site is predictive of the values of other sample sites at specified distances from the original sample site. The residuals are squared and the mean of the squared residuals is calculated for each distance. The lower the mean of each distance analyzed, the better the predictive capability of each sample site for that distance.

Egg-Yield Relationship. Multiyear field trials were done to develop sampling techniques to relate egg numbers at different plant stages to yield parameters. In 1996, 61-m ${ }^{2}$ (0.37-ha) plots were planted with hybrid Cargill 270 on 27 May at Mapleton and Prosper, $\mathrm{ND}$. Ten $3-\mathrm{m}^{2}$ sample sites were arranged in a t-pattern within each plot. A row spacing of $0.76 \mathrm{~m}$ was used in this and all subsequent trials. In 1999, a 0.6-ha plot was planted at Mapleton, ND, to hybrid Pioneer 6339 on 26 May, and a 0.4-ha plot was planted at Prosper, ND, to hybrid Cargil 270 on 28 May. At both locations, additional plots were planted on 8 June. Each plot was subdivided into 16 rectangles by using a 4 by 4 grid pattern, and samples were taken from the center of each rectangle.

In 1996, sets of five buds were harvested for sampling banded sunflower moth eggs from each of the 10 sample sites in each plot on 25 July. At that time, the plants were intermediate between plant stages $\mathrm{R} 2$ and R3. Another sample was taken on 2 August when the plants were intermediate between plant stages $\mathrm{R} 3$ and R4. At each sampling date, the buds were taken to the laboratory where the eggs on six randomly selected bracts were counted using a dissecting microscope at 8× magnification. Peng and Brewer (1996) determined that sampling eggs on six bracts per bud was representative of the total egg density on that bud. We adapted their method to sample eggs on six randomly selected bracts per bud and from five buds per site. The egg densities for a site were averaged.

At physiological maturity, five randomly chosen heads from each sample site were removed and taken to the laboratory where the seeds were hand-threshed and cleaned. Total seed weight, seed number, and percentage of banded sunflower moth damaged seed were recorded per plant and averaged for each sample site. Percentage banded sunflower moth damaged seed was determined from a 100 seed subsample of cleaned seed. The average banded sunflower moth egg densities from each sampled plant stage and sample site were regressed against the average damage per- 
centage and seed data from the same sampling sites (SAS Institute 1999).

In 1999, banded sunflower moth egg sampling was done as in 1996 except that two sets of five buds were collected from each sample site per sampling time instead of one set. Buds from plants at stages R2, R3, and R4 were sampled on 22 July, 28-29 July, and 5 August, respectively. Data collection was done as in 1996 except that we also measured seed oil content using a Maran model 5 pulsed nuclear magnetic resonance machine (Oxford Instruments PLC, Eynsham Witney, Oxon, United Kingdom). Oil percentage was measured from a randomly collected $40-\mathrm{ml}$ subsample of cleaned seed from each plant. Oil percentages are expressed at $0 \%$ moisture content. Regression analysis was done as in 1996.

In 2003, three plots were planted at Mapleton and two at Prosper, ND. The plots at Mapleton were 0.17$0.24 \mathrm{ha}$, and they were planted on 21 May. Each plot was seeded with four rows each of sunflower hybrids: Mycogen 838A, Mycogen 8377NS, Pioneer 63M80, and Agway 3733. The plots at the Prosper location were $0.26 \mathrm{ha}$, and they were planted with the same hybrids on 27 May and 5 June. The arrangements of the four rows of each hybrid were randomized within each plot with a single row of SF 128 planted around each plot and between each hybrid.

Fifteen sunflower buds per plot were sampled for banded sunflower moth eggs when plants were at stages R2 (27 July) and R3 (2 August). Egg sampling was done in situ instead of using the harvesting method of 1996 and 1999 so that the same plants sampled for eggs could be sampled for yield at plant maturity. A headband binocular magnifier was used to count the banded sunflower moth eggs on each bract. The initial bract sampled was randomly selected. Then the eggs on the bracts directly adjacent to the initial bract were counted. The process was repeated with another three bracts on the opposite side of the bud to give a total of six bracts sampled per plant. At maturity, the plants previously sampled for eggs were harvested. In addition to the seed and damage data taken in 1999, mature plant head area was measured by taking two diameter measurements at right angles to each other across the face of the sunflower head and determining the area of an ellipse. The numbers of seeds per head were counted using a FMC model EB00E seed counter (Seedburro Equipment Co., Chicago, IL). Data were regressed against banded sunflower moth egg densities (PROC REG, SAS Institute 1999).

On 26 May 2004, sunflower hybrids Mycogen 838A, Mycogen 8377NS, Pioneer 63M80, and Agway 3733 were planted at Prosper, ND. The hybrids were planted in eight-row plots $6 \mathrm{~m}$ in length. Plots were replicated five times and arranged linearly to give an overall trial dimension of 6.1 by $120 \mathrm{~m}$. A second trial was planted on 3 June. Because eight rows of each hybrid were used, a row of a standard hybrid was not planted between or around the test hybrids as in 2003.

Banded sunflower moth egg samples were taken from 10 plants per hybrid and replicate at plant stage
R3 (29 July) by using the methods of 2003. Data collection and analysis were done as in 2003. A test for homogeneity of variance was done using Levene's test of homogeneity (PROC GLM, SAS Institute 1999) to determine whether the 2003 and 2004 data sets could be combined.

Economic Injury Level. A banded sunflower moth EIL in terms of eggs per six bracts per bud was modified from Pedigo (2002); EIL $=\mathrm{C} / \mathrm{VWK}$. C is the cost of treatment per unit area, $\mathrm{V}$ is the crop market value per unit of weight, $\mathrm{W}$ is the slope of the regression between banded sunflower moth egg densities and weight loss per plant, and $\mathrm{K}$ is treatment control efficacy. Because $\mathrm{W}$ was measured on a per plant basis, a term for plant population per unit area $(\mathrm{P})$ was included in the EIL formula (EIL = C/VWPK). The EIL was developed using egg density data taken at plant stage R3 in 2003 and 2004. We assigned a value of US $\$ 19.76$ per hectare as the cost of control, a plant population of 39,520 plants per ha, an $80 \%$ control efficacy, and a market value of $\$ 0.22$ per $\mathrm{kg}$.

Economic Distance. Because the calculated EIL is based on samples taken at the field margin, an additional step was needed to apply the EIL to the entire field. We tested the relationship of banded sunflower moth egg population densities at given distances into a field to egg densities from six bracts on five buds located $6 \mathrm{~m}$ in from the field margin using the methods developed by Peng and Brewer (1996) in plot trials:

$$
\operatorname{Eggs}_{\mathrm{D}}=(1.458-0.262 \ln (\mathrm{D})) \mathrm{E} \text {. }
$$

$\mathrm{E}$ is the average egg count at the $6 \mathrm{~m}$ sample site and $\mathrm{D}$ is distance in meters along a transect into the field. In 2003, egg counts were taken on 14 transects in a field near Valley City, ND, at distances of 6 and $25 \mathrm{~m}$. In 2004 similar methods were used except that egg counts were obtained at distances of $6,25,75$, and $125 \mathrm{~m}$ along 12 transects in a field near Tower City, ND, and from four transects along a field near Valley City, ND. For both years, the egg densities from five plants at each sample distance were averaged for that site before analysis. Equation 1 was used to obtain predicted egg densities at distances into the field beyond the 6-m sampling site. We then used a paired T test to compare observed with predicated egg densities (PROC Means, SAS Institute 1999).

\section{Results}

Egg Sampling. Mean number of eggs counted using the various sampling techniques is given in Table 1 . The headband binocular magnifier method was the only technique of those tested in which the numbers of eggs counted was not significantly different from the actual number of eggs present (determined using an $8 \times$ dissecting microscope $)(F=13.94 ; \mathrm{df}=4,295$; $P<0.0001$ ). Although using a binocular headband magnifier was the most accurate (percentage of check detected) and most time efficient method to count eggs, it could not always discern multiple eggs in a cluster. However, the other sampling methods were less accurate, and they had greater variation. The 
Table 1. Mean number of banded sunflower moth eggs detected per sampling method and percentage of sampling accuracy

\begin{tabular}{lccc}
\hline \multicolumn{1}{c}{ Sampling method } & Mean & SE & \% detected $^{a}$ \\
\hline $8 \times$ microscope (check) & $20.7 \mathrm{a}$ & 1.09 & \\
Binocular 3.5 $\times$ headband & $20.2 \mathrm{a}$ & 1.12 & 97 \\
$\quad$ magnifier & $13.8 \mathrm{~b}$ & 0.88 & 67 \\
Digital photography & $14.6 \mathrm{~b}$ & 0.95 & 70 \\
$2 \times$ handheld magnifier & $12.9 \mathrm{~b}$ & 0.89 & 63 \\
Unaided vision &
\end{tabular}

MeaN.S. followed by the same letter do not differ significantly, $\alpha=$ $0.05(n=60)$

${ }^{a}$ Percentage of eggs found compared with microscope method.

binocular headband magnifier was used in all subsequent egg sampling.

In-Field Sampling. All the separate ANOVA tests for whole fields $(n=9)$ were significantly different. Thus, for fields, any single sample was unrepresentative of the population. At the scale of field side $(N=$ 33), egg counts differed significantly in eight of the 30 analyses made. Thus, if only a single sample is taken per field-side, the sample would be unrepresentative of other sites along that field-side $27 \%$ of the time.

When the results were analyzed at the scale of partial field-side (400-m span of a field-side) $(n=66)$, the results were significantly different in only four of 60 analyses. Thus, a single sample within a partial field-side was unrepresentative of the egg population only $6.7 \%$ of the time. The Press statistic indicated that banded sunflower moth egg counts at a sample site are most accurate at predicting banded sunflower moth egg populations within a distance of $200 \mathrm{~m}$ to either side of the sample (Fig. 1). These results agree with the ANOVA results showing that single samples in a partial field-side have a low risk of being unrepresentative.

Egg-Yield Relationship. In 1996, there were significant relationships between banded sunflower moth egg densities taken when plants were intermediate between plant stages $\mathrm{R} 2$ and $\mathrm{R} 3$ and seed weight $(F=$ 9.51; $\left.\mathrm{df}=1,98 ; P=0.0044 ; R^{2}=0.0799\right)$ and seed number $\left(F=9.96 ; \mathrm{df}=1,98 ; P=0.0021 ; R^{2}=0.0923\right)$; and when egg densities were intermediate between plant stages R3 and R4 and banded sunflower moth seed damage $\left(F=4.29\right.$; $\mathrm{df}=1,98 ; P=<0.0420 ; R^{2}=$ $0.042)$. Other combinations of egg densities and yield parameters were not significant (Table 2).

In 1999 at the Prosper site, mean (SE) numbers of banded sunflower moth eggs at plant stage $\mathrm{R} 2$ were 0.3 (0.2), at R3 were 24.4 (2.2), and at R4 were 17.3 (1.7) per six bracts. At Mapleton, mean (SE) numbers of eggs at R2 were $2.8(0.5)$, at R3 were 14.2 (1.5), and at R4 were 11.1 (1.2) per six bracts. Banded sunflower moth egg densities taken at plant stage $\mathrm{R} 2$ were negatively correlated with seed weight and seed number and positively correlated with seed damage. When banded sunflower moth egg densities were taken at plant stages R3 and R4, the relationships for seed weight and number were again significant, but the signs of the slopes were reversed compared with the stage $\mathrm{R} 2$ results. Seed oil percentage significantly de-

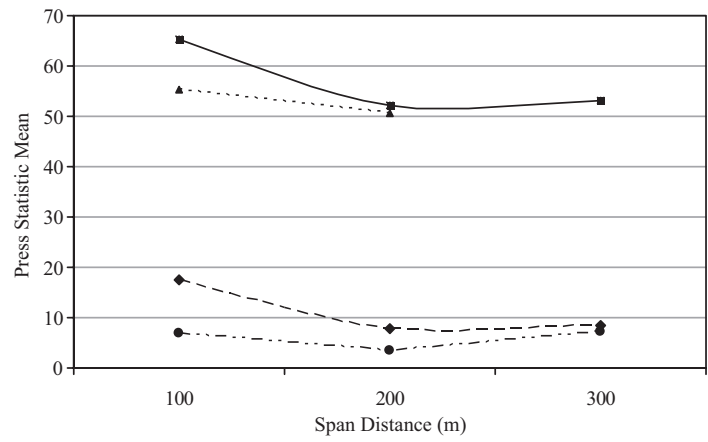

Fig. 1. Press statistics for banded sunflower moth egg count data within spans of 100-, 200-, and 300-m distances along sides of sunflower fields. Spans with the lowest Press statistic mean have the least variance. Data from four fields.

clined as egg numbers measured at stage $\mathrm{R} 4$ increased (Table 2).

In 2003, the regression of number of banded sunflower moth eggs measured at plant stages R2 and R3 with seed weight, seed number, and head area were significant. Over all locations, the mean (SE) numbers of eggs at R2 were $5.5(0.8)$ and at R3 were 9.3 (1.6) per six bracts. Egg densities at plant stage R3 but not R2 were significantly related to banded sunflower moth damage. Oil percentage was not significantly related to banded sunflower moth egg density at stage R3 (Table 3).

In 2004, the mean (SE) banded sunflower moth egg density of 25.5 (1.6) at plant stage R3 was higher than the mean of 2003. Egg densities were significantly related to seed weight, seed number, oil percentage, and seed damage. Although oil percentage was significantly related to banded sunflower moth egg density, little of the variability was explained by the relationship. Unlike in 2003, head area was not related to egg density (Table 3).

Tests for homogeneity of variance between the 2003 and 2004 data sets varied by parameters measured. The 2003 and 2004 variances of total seed weight and head area were not homogeneous (seed weight: $F=57.99$; $\mathrm{df}=1,524 ; P<0.0001 ; n=269,257)($ head area: $F=$ 25.28; df $=1,525 ; P<0.0001 ; n=270,257)$, but the variances of seed number and seed damage were homogeneous between the two data sets (seed number: $F=1.24 ; \mathrm{df}=1,140 ; P=0.26 ; n=229,212$ ) (banded sunflower moth damage: $F=0.49 ; \mathrm{df}=1,524 ; P=0.48$; $n=269,257)$.

Economic Injury Level. Using the parameters given in the methods for EIL development, the egg density data taken at plant stage R3 in 2003 resulted in a W (reduction in seed weight per banded sunflower moth egg) of $0.00068 \mathrm{~kg}$ per plant and an EIL of 4.2. In 2004, a W of $0.00029 \mathrm{~kg}$ per plant gave an EIL of 9.8. Using the average $W$ from 2003 and 2004 of 0.000485 gave an EIL of 5.9 eggs per six bracts. However, because the calculated EIL is based on samples taken at the field margin, an additional step is needed to apply the EIL to the entire field. 
Table 2. Plot means for seed and head traits from harvested plants and regression of meaN.S. on plot average numbers of banded sunflower moth eggs at two locations and from different plant stages in 1996 and 1999

\begin{tabular}{|c|c|c|c|c|c|c|c|c|}
\hline \multirow[b]{2}{*}{ Yr and plant trait } & \multirow[b]{2}{*}{ Mean (SE) } & \multirow[b]{2}{*}{ Range } & \multicolumn{6}{|c|}{ Regression } \\
\hline & & & $\begin{array}{l}\text { Plant } \\
\text { stage }\end{array}$ & $\mathrm{df}$ & $P$ value & $F$ value & Slope (SE) & $R^{2}$ \\
\hline \multicolumn{9}{|l|}{1996} \\
\hline \multirow{2}{*}{ Seed wt } & $64.2(1.4)$ & $32-105$ & $\mathrm{R} 2 / 3$ & 1,98 & 0.0044 & 9.51 & $-0.2(0.2)$ & 0.08 \\
\hline & & & $\mathrm{R} 3 / 4$ & 1,98 & N.S. & & & \\
\hline \multirow[t]{2}{*}{ Seed no. } & $1,196.5(21.0)$ & $800-1,769$ & $\mathrm{R} 2 / 3$ & 1,98 & 0.0021 & 9.96 & $-2.7(0.0)$ & 0.09 \\
\hline & & & $\mathrm{R} 3 / 4$ & 1,98 & N.S. & & & \\
\hline \multirow[t]{2}{*}{$\%$ seed damage } & $11.3(0.7)$ & $2-40$ & $\mathrm{R} 2 / 3$ & 1,98 & N.S. & & & \\
\hline & & & $\mathrm{R} 3 / 4$ & 1,98 & 0.0420 & 4.29 & $0.1(0.5)$ & 0.04 \\
\hline \multicolumn{9}{|l|}{1999} \\
\hline \multirow[t]{3}{*}{ Seed wt } & $42.4(3.7)$ & $13-78$ & $\mathrm{R} 2$ & 1,29 & $<0.0001$ & 33.96 & $-9.3(1.6)$ & 0.52 \\
\hline & $51.2(3.3)$ & $17-78$ & $\mathrm{R} 3$ & 1,29 & $<0.0001$ & 35.19 & $1.6(0.3)$ & 0.53 \\
\hline & $49.9(3.4)$ & $17-78$ & $\mathrm{R} 4$ & 1,23 & 0.0366 & 4.93 & $1.1(0.5)$ & 0.14 \\
\hline \multirow[t]{3}{*}{ Seed no. } & $842.6(69.4)$ & $298-1,393$ & $\mathrm{R} 2$ & 1,29 & $<0.0001$ & 37.54 & $-174.5(28.5)$ & 0.55 \\
\hline & $1,001.3(62.1)$ & $386-1,393$ & $\mathrm{R} 3$ & 1,29 & $<0.0001$ & 22.92 & $27.2(5.7)$ & 0.42 \\
\hline & $978.3(63.9)$ & $386-1,393$ & $\mathrm{R} 4$ & 1,23 & 0.0174 & 6.57 & $24.2(9.4)$ & 0.19 \\
\hline \multirow[t]{3}{*}{$\%$ seed damage } & $8.6(0.7)$ & $5-15$ & $\mathrm{R} 2$ & 1,14 & 0.0177 & 7.22 & $1.1(0.4)$ & 0.29 \\
\hline & $7.4(0.5)$ & $5-9$ & $\mathrm{R} 3$ & 1,8 & 0.05 & 5.13 & $-0.3(0.1)$ & 0.31 \\
\hline & $8.7(0.3)$ & 8-9 & $\mathrm{R} 4$ & & & & & \\
\hline \multirow[t]{3}{*}{ Seed oil \% } & $45.2(0.4)$ & $38-48$ & $\mathrm{R} 2$ & 1,29 & N.S. & & & \\
\hline & $44.9(0.4)$ & $38-47$ & $\mathrm{R} 3$ & 1,22 & N.S. & & & \\
\hline & $45.0(0.4)$ & $38-47$ & $\mathrm{R} 4$ & 1,23 & 0.0319 & 5.22 & $-0.1(0.1)$ & 0.15 \\
\hline
\end{tabular}

N.S., not significant.

Economic Distance. The relationship of observed egg densities at $6 \mathrm{~m}$ to predicted densities at other distances into a field described by Peng and Brewer (1996) was verified. Observed densities did not differ significantly from predicted densities in either year and at the distances tested in 2003 ( $[25 \mathrm{~m}]: n=14, t=$ $-1.22, P=0.24)$ and in $2004([25 \mathrm{~m}] n=16, t=0.36$, $P=0.72 ;[75 \mathrm{~m}] n=16, t=0.28, P=0.78)$, and $[125$ $\mathrm{m}] n=16, t=0.97, P=0.35$ ).

Using equation 1, we set Eggs $_{D}$ to equal the value of the EIL and $\mathrm{E}$ to the banded sunflower moth egg count from a 6 -m field sample site. We then rearranged the terms of the equation to solve for economic distance (ED), the distance into a field from a sample site on the field margin where a banded sunflower moth population at or above the EIL is expected.

$$
\mathrm{ED}=\ln (\mathrm{D})=((\mathrm{EIL} / \mathrm{E})-1.458) /-0.262 .
$$

Solving for the natural anti-logarithm of (D) gives

$$
\mathrm{e}^{(((\text {EIL } / E)-1.458) /-0.262)} \text {. }
$$

Using an EIL of 5.9 eggs per six bracts and a sample banded sunflower moth egg count of 15 per six bracts at a 6-m sample site, the ED is $\mathrm{e}^{(((5.9 / 15)-1.458) /-0.262)}=$ $58 \mathrm{~m}$. Thus, for this example an economically damaging

Table 3. Mean values for seed and head traits from harvested plants and regression of traits on banded sunflower moth egg counts

\begin{tabular}{|c|c|c|c|c|c|c|c|c|}
\hline \multirow[b]{2}{*}{ Yr and plant trait } & \multirow[b]{2}{*}{ Mean (SE) } & \multirow[b]{2}{*}{ Range } & \multicolumn{6}{|c|}{ Regression plant stage } \\
\hline & & & $\begin{array}{l}\text { Plant } \\
\text { stage }\end{array}$ & $\mathrm{df}$ & $P$ value & $F$ value & Slope (SE) & $R^{2}$ \\
\hline \multicolumn{9}{|l|}{2003} \\
\hline \multirow{2}{*}{ Seed wt (g) } & $112.1(4.7)$ & $12-212$ & $\mathrm{R} 2$ & 1,89 & 0.0010 & 11.68 & $-1.97(0.6)$ & 0.11 \\
\hline & $114.9(3.5)$ & 14-237 & R3 & 1,176 & $<0.0001$ & 17.22 & $-0.68(0.2)$ & 0.08 \\
\hline \multirow[t]{2}{*}{ Seed no. } & $1,469(43)$ & $183-2,464$ & $\mathrm{R} 2$ & 1,89 & $<0.0001$ & 19.32 & $-22.5(5.1)$ & 0.17 \\
\hline & $1,516(31.3)$ & $188-2,785$ & R3 & 1,176 & $<0.0001$ & 18.78 & $-6.26(1.4)$ & 0.09 \\
\hline \multirow[t]{2}{*}{$\%$ seed damage } & $1.9(0.2)$ & $0-6$ & $\mathrm{R} 2$ & 1,64 & N.S. & & & \\
\hline & $1.0(0.1)$ & $0-7$ & R3 & 1,160 & $<0.0001$ & 99.71 & $0.10(0.01)$ & 0.38 \\
\hline \multirow[t]{2}{*}{ Head area $\left(\mathrm{cm}^{2}\right)$} & $414.1(17.1)$ & $102-804$ & $\mathrm{R} 2$ & 1,90 & 0.0035 & 9.00 & $-6.4(2.1)$ & 0.08 \\
\hline & $416.1(10.7)$ & $130-829$ & R3 & 1,176 & 0.0039 & 8.53 & $-1.48(0.5)$ & 0.04 \\
\hline \multirow[t]{2}{*}{ Seed oil \% } & $36.3(0.8)$ & $19-47$ & $\mathrm{R} 2$ & 1,76 & 0.0277 & 5.04 & $-0.27(0.1)$ & 0.05 \\
\hline & $36.5(0.5)$ & $4-46$ & R3 & 1,157 & N.S. & & & \\
\hline \multicolumn{9}{|l|}{2004} \\
\hline Seed wt (g) & $71.6(1.7)$ & 13-183 & R3 & 1,255 & $<0.0001$ & 22.21 & $-0.29(0.6)$ & 0.08 \\
\hline Seed no. & $1125(25)$ & $272-2,338$ & R3 & 1,255 & $<0.0001$ & 56.58 & $-6.49(0.9)$ & 0.18 \\
\hline$\%$ seed damage & $1.4(0.1)$ & $0-11$ & R3 & 1,210 & $<0.0001$ & 188.15 & $0.05(0.0)$ & 0.48 \\
\hline Head area $\left(\mathrm{cm}^{2}\right)$ & $328.4(6.7)$ & $153-754$ & R3 & 1,255 & N.S. & N.S. & N.S. & N.S. \\
\hline Seed oil \% & $39.0(0.2)$ & $29-47$ & R3 & 1,247 & $<0.0001$ & 15.67 & $-0.03(0.1)$ & 0.06 \\
\hline
\end{tabular}
taken at different plant stages in oilseed sunflower in 2003 and 2004

N.S., not significant. 

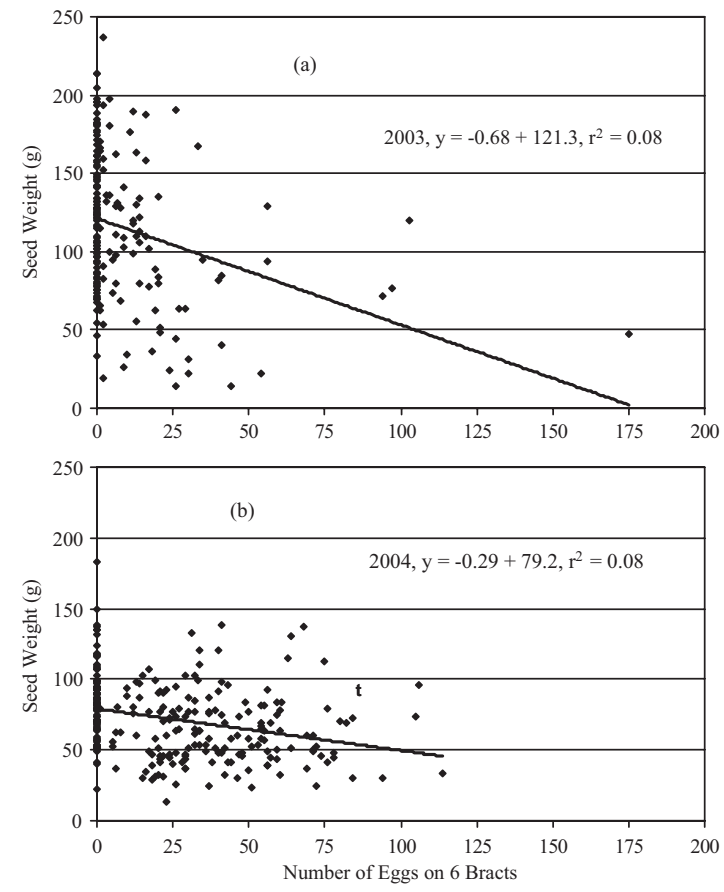

Fig. 2. Regression of seed weight per plant on six bract egg counts taken at plant stage R3 in 2003 (a) and 2004 (b).

banded sunflower moth population is expected to extend $58 \mathrm{~m}$ into the field from the field margin sample site.

\section{Discussion}

Although the 1996 and 1999 results suggested that banded sunflower moth egg numbers affected seed weight, seed number, and seed damage, the year to year results were not consistent and little of the variation in seed traits was explained by egg numbers. This probably occurred because a destructive sampling procedure was used that only indirectly related egg densities to the other parameters measured for the sample site.

In 2003 and 2004, the experimental design was changed to improve accuracy. Instead of destructive sampling, eggs were sampled on plants in situ so a direct relationship between egg densities at each plant stage and the resulting yield and damage measures could be better understood. Because the 1999 data set indicated that banded sunflower moth egg densities taken at plant stages R2 and R3 had the most effect on the variables explored, measurements were confined to those plant stages in 2003.

In 2003, egg densities at plant stage R2 and R3 were significantly related to seed weight and number. However, seed damage was only related to plant stage R3 egg densities. Because larvae developing from eggs oviposited at plant stage $\mathrm{R} 2$ probably complete development before many seeds are present, they have little opportunity to cause seed damage. However, larvae arising from eggs oviposited on R3 stage plants
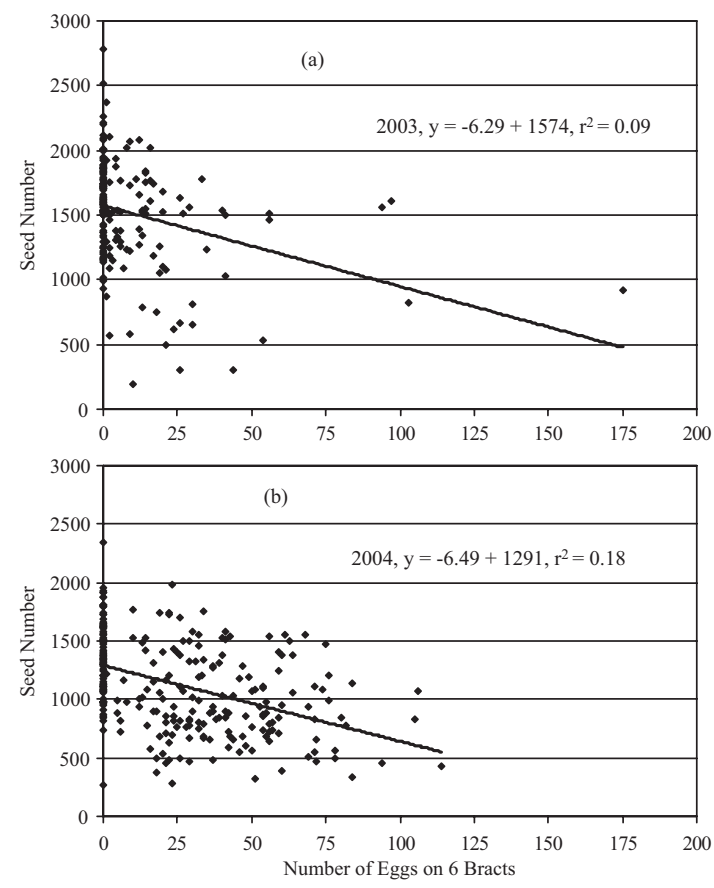

Fig. 3. Regression of seed number per plant on six bract egg counts taken at plant stage R3 in 2003 (a) and 2004 (b).

have greater access to developing seeds and consequently cause more seed damage. Overall, the variation in total seed weight, seed number, and damage percentage was best explained by sampling at plant stage R3 for banded sunflower moth eggs. Therefore, in 2004 banded sunflower moth egg densities were taken only at plant stage R3.

The relationships between egg densities and seed weight in 2003 and 2004 were significant (Fig. 2; Table 3 ). In both years, seed weight declined as number of eggs at plant stage R3 increased. Similarly, number of seeds declined significantly with increasing egg numbers in 2003 and 2004 (Fig. 3; Table 3). However, because the variances of seed weight between the 2003 and 2004 data were not homogeneous, each year was analyzed separately. Both years indicated that banded sunflower moth egg densities sampled at plant stage R3 can predict reductions in total seed weight, seed number, and percentage of seed damage. The relationship between egg densities and total seed weight was used to develop an EIL.

Although oil percentage is a component of the EIL for the red sunflower seed weevil, Smicronyx fulvus LeConte in oilseed sunflower (Peng and Brewer 1995), oil percentage was not significantly related to banded sunflower moth egg densities. Thus, only seed weight was used to define the relationship between egg densities and yield loss.

The EIL developed as part of this study offers several advantages compared with one based on sampling moths (Charlet et al. 2002). Eggs are easier to locate and count than moths, and the sampling protocol does not require going into the field interior. If an economic 
population of the banded sunflower moth is detected at any site along a field margin, the extent of the penetration of the economically damaging population into the field along a transect from the sampling site can be estimated using economic distance. By determining both the EIL and economic distance, field areas expected to be subject to economically damaging banded sunflower moth populations can be mapped.

The development of methodology to survey eggs, a corresponding EIL, and the economic distance technique provides sunflower producers and scouts with an accurate, time-efficient, and inexpensive way to monitor banded sunflower moth populations and to predict expected yield losses to specific areas of a field. Another advantage of sampling eggs is that there is a period of $\approx 10 \mathrm{~d}$ between sampling and early anthesis (stage R5) when control measures (normally an insecticide application) would need to be taken (Charlet and Busacca 1986).

By using these procedures, producers and scouts can precisely target chemical applications to specific areas where banded sunflower moth egg populations are expected to be economically damaging. Reducing the area receiving insecticide treatments will immediately increase producer profits and have the added benefit of reducing deleterious effects on nontarget insect and other populations and decreasing the likelihood of banded sunflower moth developing pesticide resistance. The findings of this study, specifically the concept of economic distance, might be applicable to other pest species and cropping systems where there is an edge effect. Field margin sampling reduces sampling time and when combined with the economic distance procedure promises to reduce pesticide use and its deleterious effects as well as increase producer profits.

\section{Acknowledgments}

We express sincere appreciation to cooperators Anthony Thilmony and Dave Torgenson, research technician Gene
Schmidt, and research assistants Kate Rice and Ajay Jyoti for contributions. We thank Jerry Miller (USDA-ARS) for allowing us to use the NMR analyzer and Jeff Terpstra for statistical help.

\section{References Cited}

Beregovoy, V. H., and J. G. Riemann. 1987. Infestation phenology of sunflowers by the banded sunflower moth, Cochylis hospes (Cochylidae: Lepidoptera) in the Northern Plains. J. Kans. Entomol. Soc. 60: 517-527.

Bergmann, J. D. 1989. Infestation phenology and survival of the banded sunflower moth Cochylis hospes Walsingham. Ph.D. dissertation, North Dakota State University, Fargo, ND.

Charlet, L. D., and J. D. Busacca. 1986. Insecticidal control of banded sunflower moth, Cochylis hospes (Lepidoptera: Cochylidae), larvae at different sunflower growth stages and dates of planting in North Dakota. J. Econ. Entomol. 79: $648-650$.

Charlet, L. D., and T. A. Gross. 1990. Bionomics and seasonal abundance of the banded sunflower moth, Cochylis hospes (Lepidoptera: Cochylidae) on cultivated sunflower in the Northern Great Plains. J. Econ. Entomol. 83: 135-141.

Charlet, L. D., P. A. Glogoza, and G. J. Brewer. 2002. Banded sunflower moth. N. Dakota Ext. Serv. Bull. E-823 (revised).

Pedigo, L. P. 2002. Entomology and pest management, 4th ed. Prentice Hall, Upper Saddle River, NJ.

Peng, C., and G. J. Brewer. 1995. Economic injury levels for the red sunflower seed weevil (Coleoptera: Curculionidae) infesting oilseed sunflower. Can. Entomol. 127: 561568.

Peng, C., and G. J. Brewer. 1996. Spatial distributions and sampling plans for the banded sunflower moth eggs in sunflower. Entomol. Exp. Appl. 79: 235-239.

SAS Institute. 1999. SAS OnlineDoc, version 8. SAS Institute, Cary, NC. (http://v8doc.sas.com/sashtml/).

Schneiter, A. A., and J. F. Miller. 1981. Description of sunflower growth stages. Crop Sci. 21: 901-903.

Received 18 July 2006; accepted 2 February 2008 